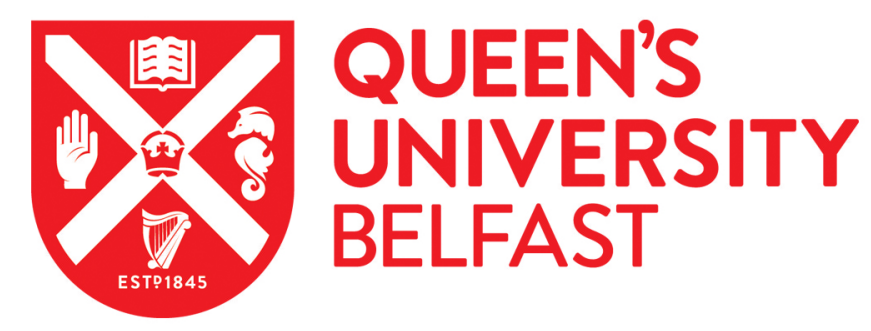

\title{
Accuracy of LightCycler(®) SeptiFast for the detection and identification of pathogens in the blood of patients with suspected sepsis: a systematic review and meta-analysis
}

Dark, P., Blackwood, B., Gates, S., McAuley, D., Perkins, G. D., McMullan, R., Wilson, C., Graham, D., Timms, K., \& Warhurst, G. (2015). Accuracy of LightCycler(®) SeptiFast for the detection and identification of pathogens in the blood of patients with suspected sepsis: a systematic review and meta-analysis. Intensive Care Medicine, 41(1), 21-33. https://doi.org/10.1007/s00134-014-3553-8

\section{Published in:}

Intensive Care Medicine

\section{Document Version:}

Peer reviewed version

Queen's University Belfast - Research Portal:

Link to publication record in Queen's University Belfast Research Portal

\section{Publisher rights}

Copyright 2015 Springer

The final publication is available at Springer via http://dx.doi.org/10.1007/s00134-014-3553-8

\section{General rights}

Copyright for the publications made accessible via the Queen's University Belfast Research Portal is retained by the author(s) and / or other copyright owners and it is a condition of accessing these publications that users recognise and abide by the legal requirements associated with these rights.

Take down policy

The Research Portal is Queen's institutional repository that provides access to Queen's research output. Every effort has been made to ensure that content in the Research Portal does not infringe any person's rights, or applicable UK laws. If you discover content in the

Research Portal that you believe breaches copyright or violates any law, please contact openaccess@qub.ac.uk. 
Accuracy of LightCycler Septi Fast for the detection and identification of pathogens in the blood of patients with suspected sepsis: a systematic review and meta-analysis

Paul Dark ${ }^{1,2,3}$, Bronagh Blackwood ${ }^{4}$, Simon Gates $^{5}$, Danny McAuley ${ }^{4}$, Gavin D Perkins $^{5,6}$, Ronan McMullan ${ }^{7}$, Claire Wilson ${ }^{1,3}$, Daniel Graham ${ }^{1,3}$, Kate Timms ${ }^{1,3}$ Geoffrey Warhurst ${ }^{1,3,8}$.

1. Infection, Injury and Inflammation Research Group, Biomedical Facility, Clinical Sciences, Manchester Academic Health Sciences Centre, Salford Royal NHS Foundation Trust, Salford, Greater Manchester, M6 8HD, UK

2. Intensive Care Unit, Salford Royal NHS Foundation, Salford, Greater Manchester, M6 8HD, UK

3. Institute of Inflammation and Repair, Faculty of Medical and Human Sciences, University of Manchester, M13 9PT, UK

4. Centre for Infection and Immunity, Queen's University, Belfast, BT9 7AE, UK

5. Clinical Trials Unit, Warwick Medical School, University of Warwick, Coventry, CV4 7AL, UK

6. Heart of England NHS Foundation Trust, Birmingham Heartlands Hospital, Birmingham, B9 5SS, UK

7. Department of Medical Microbiology, Royal Victoria Hospital, Belfast, BT12 6BA, UK

8. Biomedical Research Institute, School of Environment \& Life Sciences, University of Salford, Manchester Academic Health Sciences Centre, Salford, M5 4WT, UK

Key words: sepsis, bloodstream infection, real-time PCR, diagnostic accuracy 


\section{Abstract}

Purpose. There is an urgent need to develop diagnostic tests to improve the detection of pathogens causing life-threatening infection (sepsis). SeptiFast is a CEmarked multi-pathogen real-time PCR system capable of detecting DNA sequences of bacteria and fungi present in blood samples within a few hours. We report here a systematic review and meta-analysis of diagnostic accuracy studies of SeptiFast in the setting of suspected sepsis.

Methods. A comprehensive search strategy was developed to identify studies that compared SeptiFast with blood culture in suspected sepsis. Methodological quality was assessed using QUADAS. Heterogeneity of studies was investigated using a coupled forest plot of sensitivity and specificity and a scatter plot in Receiver Operator Characteristic space. Bivariate model method was used to estimate summary sensitivity and specificity.

Results. From 41 phase III diagnostic accuracy studies, summary sensitivity and specificity for SeptiFast compared with blood culture were 0.68 (95\% Cl 0.63-0.73) and $0.86(95 \% \mathrm{Cl} 0.84-0.89)$ respectively. Study quality was judged to be variable with important deficiencies overall in design and reporting that could impact on derived diagnostic accuracy metrics.

Conclusions. SeptiFast appears to have higher specificity than sensitivity, but deficiencies in study quality are likely to render this body of work unreliable. Based on the evidence presented here, it remains difficult to make firm recommendations about the likely clinical utility of SeptiFast in the setting of suspected sepsis. recommend that future studies should include well designed and reported clinical

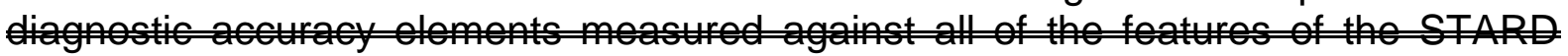
eriteria to help inform the subsequent design of much needed interventional studies in the management of suspected sepsis.

Word count: $\underline{225} 241$ 


\section{$\underline{\text { Introduction }}$}

While rapid identification and treatment of sepsis is associated with the best outcomes, sepsis can be difficult to diagnose and to differentiate from other common non-infectious causes of systemic inflammation including trauma, surgery and ischaemia-reperfusion [1]. Confirmation of sepsis, therefore, relies on objective diagnostic evidence for infection, including attempts to detect and identify live pathogens from blood samples by microbiological culture techniques [2, 3].

In the setting of sepsis, blood cultures do not always provide high diagnostic accuracy for infection in a timely manner, routinely taking several days before a positive result is available and are often negative [4]. The time between initial clinical suspicion and confirmation of infection, results in the early use of empirical broad spectrum antimicrobial drugs because treatment delay is associated with substantial increases in mortality [5-7]. Unnecessary and/or prolonged broad spectrum antimicrobial use is an inevitable consequence, which is associated with the development of drug resistant pathogens, Clostridium difficile infections, a range of avoidable adverse effects, as well as high costs [5]. An urgent global challenge has emerged [8], therefore, to develop techniques that could provide accurate diagnostic information within a short timeframe of clinical signs appearing and so allow more informed use of antibiotic therapy at an early stage.

Real-time PCR technology can detect minute amounts of pathogen DNA in patient blood samples with results available within hours [9]. Laboratory validation studies have focused on two approaches using PCR for genomic amplification with either (a) broad range detection of bacterial or fungal DNA with universal primers, followed by 
species identification using a post-PCR technique such as gene sequencing or electrospray mass spectrometry or (b) using species-specific hybridisation probes that provide direct confirmation of the species present [10]. While the laboratory analytical accuracy of these techniques for the detection of pathogen DNA in blood has been evaluated, there is a lack of reported clinical trial data to define the utility of such tests in patients $[2,10]$. This has been due in part to the lack of standardised technology platforms that meet accepted regulatory standards for clinical diagnosis.

SeptiFast, manufactured by Roche Diagnostics, GmbH, Mannheim, Germany and run on their real-time PCR instrument (the LightCycler®), was the first real-time PCR based system to be awarded a Conformité Européenne (CE) mark for simultaneous pathogen detection and identification in suspected bloodstream infection [11]. The system uses a multiplex approach, which allows detection of the most common pathogen species causing bloodstream infection in a single blood sample (Table 1). Identification of the pathogens is based on the use of species-specific probes targeting the internal transcribed spacer region between the $16 \mathrm{~S}$ and $23 \mathrm{~S}$ areas of ribosomal DNA of bacteria and between the $18 \mathrm{~S}$ and $5.8 \mathrm{~S}$ ribosomal regions of the fungal genome. SeptiFast has been assessed at the laboratory level on clinical isolates and shown to have good analytical specificity and exclusivity, confirming its analytical validity [11]. Numerous clinical diagnostic studies have been reported since SeptiFast gained its CE-mark in 2006, predominantly focused on suspected sepsis. Chang and colleagues have reported a diagnostic accuracy systematic review of published full journal papers to 2012, with SeptiFast as the index test, but with various reference standards used to produce composite overall diagnostic accuracy metrics [12]. Based on their interpretation of the evidence presented, they 
recommend that SeptiFast can be used to confidently diagnose bloodstream infection [12].

As part of a government commissioned Health Technology Assessment of SeptiFast in the United Kingdom [13], we report a more comprehensive diagnostic accuracy systematic review of SeptiFast focused on the setting of suspected sepsis and where blood cultures were used as the reference standard. This systematic review was piloted and registered with PROSPERO, the NIHR International Prospective Register of Systematic Reviews, in 2011 [14] and the study protocol was piloted and published in 2012 [15]. 
Methods

Inclusion criteria of studies:

Participants

Patients suspected of developing sepsis, including adults and children, who required blood cultures irrespective of where their care was being delivered, and including suspected community or hospital acquired infection.

Target conditions

Suspected sepsis, including severe sepsis and septic shock [16].

Index test

LightCycler® SeptiFast as the index test on blood specimens for the detection and simultaneous identification of bacterial and fungal pathogens [11].

Comparator test (reference standard)

Blood culture for the detection and identification of bloodstream bacterial and fungal pathogens was used as the reference test [4]. 


\section{Types of studies}

We included any clinical diagnostic accuracy study that compared the index real-time PCR test with standard culture results performed on a patient's blood sample during the management of suspected sepsis.

Search methods for identifying studies:

Electronic searches

We searched the Cochrane Database of Systematic Reviews, the Database of Abstracts of Reviews of Effects (DARE), the Health Technology Assessment Database (HTA), the NHS Economic Evaluation Database (NHSEED), The Cochrane Library, MEDLINE, EMBASE, ISI Web of Science, BIOSIS Previews, MEDION and the Aggressive Research Intelligence Facility database (ARIF). The CE mark for the index test was announced in January 2006; therefore, this systematic review only considered publications from this date in humans. There were no language restrictions in the electronic search for studies.

\section{Search terms/search strategy}

Specific search strategies were developed for each electronic database, commencing with MEDLINE (published previously) [14, 15]. The MEDLINE strategy was adapted for each subsequent database. All electronic searches were piloted prior to publication of our review protocol in 2012 and all searches were finally updated at the end of April 2014. 


\section{Other resources}

Backward tracking was performed by hand-searching the reference lists of all relevant articles uncovered from the electronic searches and forward tracking using the keyword 'SeptiFast' with ISI Citation Indices and Google Scholar and with a conference proceedings search using the Web of Science ISI Proceedings (from January 2006 to April 2014). We requested reference lists held by the only manufacturer of the index test (Roche Diagnostics) and requested any clinical diagnostic accuracy data collected by Roche Diagnostics to file for the CE mark. In addition, we searched for unpublished studies and ongoing trials involving the SeptiFast platform in the following online registers: http://www.nlm.nih.gov/hsrproj, http://www.controlled-trials.com/mrct/, $\quad$ http://portal.nihr.ac.uk/Pages/Portfolio.aspx and http://www.who.int/trialsearch, with identified corresponding authors of eligible trials and content experts contacted to identify potentially relevant studies and associated data.

Data collection and analysis:

Selection of studies (Salford, UK)

The selection of titles and abstracts was conducted by review authors (CW, DG, KT and PD) using the inclusion criteria detailed above. The full papers of all abstracts deemed eligible (by any reviewer) were obtained and read to determine their inclusion in the review. Conference abstracts and journal correspondences were included if they met the inclusion criteria and the corresponding author was contacted to request any further information about their study or about full 
publications in preparation. Conference abstracts were not included when reporting duplicate data contained in a subsequent paper. We resolved any disagreement for inclusion with discussion between the reviewers.

Assessment of methodological quality (Belfast and Warwick, UK)

Independent reviewers from Belfast (DM, RM, BB) and Warwick (GDP) assessed the quality of selected studies using a specific checklist, published previously [15] adapted from the QUADAS tool [17]. Each question on the checklist was answered with a yes/no response or noted as unclear if insufficient information was reported to enable a judgement to be made, and the reasons for the judgement made was documented. Review authors assessed methodological quality independently. Any subsequent discrepancies were then adjudicated and resolved by a systematic review methods expert (BB) and an infection diagnostic expert (RM).

\section{Data extraction}

A standard set of data was searched for and extracted where possible from each study using a tailored data extraction form (details published previously) [15] by review authors at Belfast and Warwick. Reviewers extracted data independently and any discrepancies were adjudicated and resolved by a systematic review methods expert (BB) and an infection diagnostic expert (RM). 
Statistical analysis and data synthesis:

Statistical analysis and data synthesis were planned and performed independently by a statistician (SG). Estimates of the combined sensitivity and specificity, with $95 \%$ confidence intervals, were made using Reitsma's bivariate method [18]. Results were displayed as summary ROC plots, with $95 \%$ confidence regions and $95 \%$ prediction regions defined by Harbord as "the region within which, assuming the model is correct, we have $95 \%$ confidence that the true sensitivity and specificity of a future study should lie" [19]. An overall summary for all studies with useable data was produced, and subgroup analyses separating studies by:

(a) Type of publication: full papers versus abstracts;

(b) Age of participants: adult versus neonate/child (this analysis omitted studies where the population was mixed or unclear);

(c) Hospital setting: emergency department versus other hospital setting, ICU versus other hospital setting (this analysis omitted studies where settings were mixed or unclear);

(d) Co-morbidity: if sufficient data available to allow comparisons;

(e) Commercial sponsorship: stated involvement of Roche Diagnostics versus no statement.

For all subgroup analyses, summary ROC curves were produced with pooled estimates of sensitivity and specificity for each group, and tested whether the subgrouping explained a significant amount of additional variation using the difference in -2log likelihood statistics between the sub-grouped and overall models. 
No attempts were made to quantify potential sources of study bias in this systematic review as the available methodologies have not been validated for use in relation to diagnostic test meta-analyses (http://srdta.cochrane.org/handbook-dta-reviews).

Analyses were performed using SAS 9.3 (SAS Institute Inc. North Carolina, USA) and Review Manager (RevMan) [Computer program]. Version 5.3. Copenhagen: The Nordic Cochrane Centre, The Cochrane Collaboration, 2012.

\section{$\underline{\text { Results }}$}

Study inclusion:

We identified 2759 citations in total, of which 66 were considered potentially suitable (Figure 1). After full text review externally at Belfast and Warwick, and having contacted corresponding authors for any extra data in the case of conference abstracts and journal correspondences, 24 studies were excluded as it proved impossible to derive a 2 by 2 table to calculate required diagnostic metrics. In addition, one abstract was removed as the study data were co-reported in a full paper and another abstract was replaced by a full paper that was sent to us by the authors. In total, 41 studies were included in the final analysis (30 papers, 9 conference abstracts and 2 correspondences - summarised in Table 2). 
Study quality:

Our independent external reviewers reported variable study quality and, although studies reported as full papers were associated with the best quality measures, there were important deficiencies overall in study design and reporting (Figure 2). Reviewers agreed that all of the studies selected aimed to compare test results from SeptiFast with blood culture and that the reported blood sampling for these tests was such that disease progression or regression bias would have been avoided. Blood culture, as the reference standard, appeared to have been applied to patients equally in a way that both partial (work-up) bias and verification bias were likely avoided. However the reference standard was not always adequately described, including blood sampling methods and the prevalence of defined contamination as a potential source of false positive culture results. Comparisons of the results of SeptiFast with blood culture at genus/species level were often difficult to adjudicate by reviewers, with no clear standards of reporting followed. The chance of misclassification when comparing the reference and index tests was therefore thought to be likely, impacting on the derived diagnostic accuracy metrics. In some studies, it was not clear how well the CE-marked protocol for SeptiFast had been followed, including how blood samples had been stored/handled prior to assay delivery. Assay failure rates were rarely reported. There was a universal lack of reported blinding of both reference standard and index tests such that reviewers believed that incorporation bias was highly likely. Overall, reviewers agreed that none of the included studies, as reported, met the Standards for Reporting Diagnostic Accuracy (STARD) criteria in full [62], and in some cases there were significant deficiencies (Figure 2). 
Study characteristics and patient populations:

Studies included patient cohorts from a wide range of age and settings (Table 2) representing a total of 7,727 patients contributing 10,493 episodes of suspected sepsis. The median prevalence of blood culture positivity in this group of patients was $17 \%$ (inter-quartile range $13-25 \%$ ). Lack of uniform reporting made it difficult for reviewers to classify studies, with a variety of care settings, outcomes and alternative clinical reference standards reported alongside the direct comparison of SeptiFast with blood culture results. However, our external reviewers were able to identify age classes (neonate, child and adult), setting classes (emergency department, hospital setting, and intensive/critical care), commercial sponsorship (stated involvement of Roche Diagnostics or no statement) and a group of studies that focused on haemato-oncology patients. In addition, studies were assigned a diagnostic evidence level III [20] in each case.

Estimated summary diagnostic accuracy of SeptiFast:

Figure 3 shows the coupled forest plots of sensitivity and specificity for each study and Figure 4 displays the scatter plot in ROC space (plotting sensitivity against 1 specificity for each study). Summary sensitivity and specificity for SeptiFast compared with blood culture, estimated using the bivariate model method, were 0.68 $(95 \% \mathrm{Cl} 0.63-0.73)$ and $0.86(95 \% \mathrm{Cl} 0.84-0.89)$ respectively, suggesting that a positive blood test at genus/species level returned by SeptiFast in the setting of a patient with suspected sepsis could have higher diagnostic value (rule-in) than a negative test result (rule-out) when compared with blood culture. 
Exploration of subgroups:

Subgroups were investigated and estimated pooled diagnostic accuracy metrics produced for each group. Table 3 summaries these results and shows that in each case sub-grouping did not explain any significant amount of additional variation in sensitivity or specificity when compared with the overall models. There were insufficient studies reporting solely in paediatric populations to allow analysis.

\section{Discussion}

Our comprehensive systematic review was designed to help understand the estimated combined diagnostic accuracy of SeptiFast in detecting and identifying bacterial and fungal pathogens in the blood of patients with suspected sepsis. We included 41 studies reporting on a total of 10,493 SeptiFast tests when compared with blood culture.

Estimated combined results for sensitivity and specificity suggested that SeptiFast has a higher specificity than sensitivity. For the healthcare team, this implies that positive blood tests returned by SeptiFast at pathogen genus/species level could have higher diagnostic utility (as a rapid rule-in test) than negative results (as a rapid rule-out test), at least when compared with blood culture. The apparent confidence in this statement is greater for specificity than sensitivity (Figures 3 and 4) because the median event rate of $17 \% \mathrm{BC}$ positivity for the studies means that the majority of reference tests performed was negative. 
The clinical interpretation of these diagnostic accuracy results is that negative SeptiFast tests could reasonably be false-negatives (expressed as a low overall diagnostic sensitivity), explained in part by pathogens detected in blood culture that were not on the PCR test panel. $\underline{\text { In the future, this could suggest that developing }}$ molecular tests that incorporate wider test panels of pathogens may be expected to provide greater diagnostic sensitivity (fewer false negative results) giving clinicians greater confidence in a rapid negative test result. In addition, despite a higher estimated overall specificity, when compared with sensitivity, the upper confidence interval did not reach $90 \%$. Specificity of SeptiFast, when compared with culture, will be limited by the presence of false positive results - a positive PCR in the setting of a negative blood culture. In some studies $[40,41]$, a proportion of these false-positive results were reported to be concordant with culture positivity from samples other than blood, suggesting that in some cases sepsis a positive SeptiFast result may reflect infection not detectable by blood culture. However, overall, there are no clear explanations for all of these false-positive and false-negative SeptiFast results because no systematic investigation has been undertaken linking laboratory performance with clinical diagnostic accuracy. In addition, it remains extremely difficult to speculate what implications these diagnostic accuracy results may have for direct clinical care because SeptiFast does not report antibiotic sensitivity data (other than identifying the $M e c A$ gene confirming meticillin resistance following detection of $S$. aureus [11]) and there have been no systematic interventional clinical trials reported to date on the overall impact on clinical, laboratory and

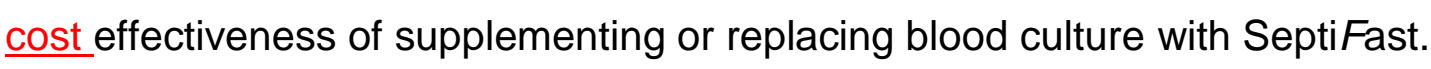


All diagnostic metrics were reported using blood culture as the reference standard because this formed the basis of both the original laboratory diagnostic validity studies for SeptiFast [11] and the subsequent body of clinical diagnostic accuracy studies reported here. However, we accept that there could be limitations to this standard, particularly in the setting of intercurrent antimicrobial therapy. While antibiotic exposure data were rarely reported in the included studies, it is likely, for example, that patients in intensive care units were likely already exposed to broad spectrum antibiotics [33]. It is interesting to note that included studies recruiting solely from intensive care appeared to have slightly worse diagnostic metrics (both sensitivity, with higher rates of false negatives; and specificity, with higher rates of false positives) when compared with the results of blood culture (Table 3), but not to a significant level. Antimicrobial exposure is not the only factor that will distinguish patients in intensive care from other hospitalised patients, but it does seem particularly pertinent because of the widespread use of blood culture as the reference standard in these studies. The potential impact of antimicrobials in producing positive PCR tests with blood and associated negative blood culture results (false positives in our analysis) leads one to question blood culture as a relevant reference standard and challenges clinicians to consider a positive PCR test in this setting as a true positive, providing additional diagnostic information in patients with suspected sepsis. However, explaining the potential impact of antimicrobials on increasing false negative PCR tests (i.e. where associated blood culture tests are positive) is more problematic. In practice, a wide range of factors are known to influence the diagnostic accuracy of blood cultures [4] and, in our view, it is important to develop further and adopt statistical techniques that avoid the need for comparison to a single reference standard to provide a more meaningful estimate 
of the clinical reliability of emerging molecular diagnostic tests [63]. However, to achieve this aim, diagnostic studies must be designed and reported to accepted international standards [62].

However, we do not know the full extent of this problem or indeed whether studies have deliberately included or excluded such patients. In addition, septifast was developed to simultaneously detect and identify a panel of the most common pathogens based on reported international blood culture suveillance data [11]. Therefore, in the absence of an internationally agreed approach to an alternative

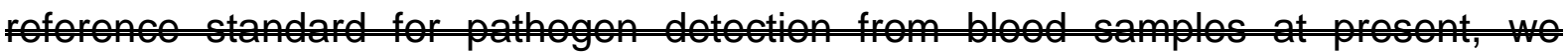
believe that a culture-based reforencestandard provided the most robust approach for this

During the implementation of our review, another systematic review has reported on the diagnostic accuracy performance of SeptiFast [12]. Chang and colleagues synthesised improved overall diagnostic accuracy metrics for SeptiFast when compared with our own review: sensitivity 0.75 (95\% Cl: $0.65-0.83)$ vs $0.68(95 \% \mathrm{Cl}$ $0.63-0.73)$ and specificity $0.92(95 \% \mathrm{Cl}: 0.90-0.95)$ vs $0.86(95 \% \mathrm{Cl} \quad 0.84-0.89)$ respectively. However, there were important differences between our reviews. Chang used a basic keyword search strategy (ending in 2012) for journal papers only, risking publication bias. We used a systematic and comprehensive search strategy that aimed to avoid any publication bias. Chang reports SeptiFast results against various reference standards to produce composite overall diagnostic 
accuracy metrics. We report overall diagnostic accuracy metrics from the results of SeptiFast measured against blood culture. These factors may have contributed to inflate the overall diagnostic accuracy metrics for SeptiFast reported by Chang when compared with the results of our own systematic review.

Diagnostic accuracy studies included in our review were performed within the challenging care environments for patients with suspected sepsis. Clinical diagnostic accuracy studies, in general, are difficult to perform well and often fall short in terms of study quality. Our independent reviewers found significant deficiencies when assessing the quality of design and reporting for studies incorporating SeptiFast as the index test. For both papers and abstracts, the application of reference and index tests were the only elements that were reported consistently, raising significant concern about the possible effects of numerous sources of bias on the derived summary estimates of SeptiFast test performance. Indeed, the 95\% prediction region in ROC space in Figure 4 shows considerable uncertainty about the likely true sensitivity and specificity of a future study. Therefore, despite the considerable international effort in determining the likely diagnostic accuracy of SeptiFast in the setting of suspected sepsis, we are not confident in the current body of evidence because of the overall weaknesses in study design and reporting outlined in our review. Based on these findings, we do not agree with Chang and colleagues who state that "in the presence of a positive SeptiFast result in a patient with suspected bacterial or fungal sepsis, a clinician can confidently diagnose bacteremia or fungemia and begin appropriate antimicrobial therapy, while forgoing unnecessary additional diagnostic testing" [12]. For example, in a high prevalence population, 
such as a patient admitted to intensive care with septic shock, broad spectrum antibiotics should have been delivered quickly, well before the results of blood culture (or indeed SeptiFast) will be available [2]. In this setting, the pre-test probability for circulating pathogens is likely high and there is an increased chance of delivering positive SeptiFast and blood culture tests, particularly if blood is sampled $\underline{\text { before antimicrobial treatment commences. Delivering a positive SeptiFast test }}$ ahead of a blood culture result in this setting might help the intensive care clinician consider early antibiotic de-escalation based on the detected pathogen species. However, SeptiFast does not provide comprehensive antimicrobial susceptibility information and crucial clinical decisions based only on pathogen species may be unwise in this setting and, as described previously, remains untested in carefully controlled clinical trials. Furthermore, we do not agree with Chang and colleagues that returning a negative SeptiFast result, even in a low prevalence population, "may justify withholding antibiotics" [12]. For example, a patient admitted to an emergency department with clinical features of sepsis, in the absence of circulatory compromise or organ dysfunction, is likely to have a low pre-test probability for circulating pathogen. Delivering a negative SeptiFast test to the clinical team over the subsequent hours may provide some confidence in excluding serious infection as the cause of symptoms. However, given the high rate of false-negative SeptiFast tests identified in our review, the clinician is not completely confident and could miss some cases of bacteraemia and other infections outside the circulation. Based on the evidence presented here, we are concerned that clinical decisions about treatment interventions/adjustments (notably antimicrobial chemotherapy) based on SeptiFast results, potentially delivered within hours of the suspicion of sepsis, could expose patients to risk because inadequately managed sepsis is 
associated with high mortality and rapid appropriate antimicrobial choices are crucial for survival [2].

Our views, evidenced by the present systematic review, supports current international guidelines on diagnosis and treatment of sepsis which indicate that there is limited clinical experience with non-culture-based diagnostic methods, such as SeptiFast, and that more high-quality clinical studies are needed before any firm recommendations can be made about their potential utility [2]. We recommend that future clinical studies incorporating SeptiFast, or any other novel infection/sepsis diagnostic, should include well designed and reported clinical diagnostic accuracy elements measured against all of the features of the STARD criteria [62]. Much needed clinical intervention studies in the setting of suspected sepsis remain difficult to design and justify until higher quality clinical diagnostic accuracy evidence is available.

Manuscript word count: $\underline{3,829} \mathbf{3}, 313$ 
Table 1: Pathogens detectable using LightCycler® Septi Fast test

Gram-negative bacteria

Escherichia coli

Klebsiella

(pneumoniae/oxytoca)

Serratia marcescens

Enterobacter

(cloacae/aerogenes)

Proteus mirabilis

Acinetobacter baumanni

Pseudomonas aeruginosa

Stentrophomonas maltophilia
Gram-positive bacteria

Staphylococcus aureus

Coagulase-negative

staphylococci*

Streptococcus pneumonia

Streptococcus spp."

Enterococcus faecium

Enterococcus faecalis
Fungi

Candida albicans

Candida tropicalis

Candida parapsilosis

Candida glabrata

Candida krusei

Aspergillus fumigatus

*Single probe detects a group of staphylococcal pathogens including S. epidermidis, S. haemolyticus ${ }^{\#}$ Single probe detects a group of streptococcal pathogens including S. pyogenes, S. agalacticae, $S$. mitis 
Table 2: Summary of studies included in review. \# indicates haemato-oncology study cohorts.

\begin{tabular}{|c|c|c|c|c|c|c|c|c|c|}
\hline First author & Year & Manuscript type & $\begin{array}{l}\text { Study } \\
\text { country }\end{array}$ & Patient setting & $\begin{array}{c}\text { Age } \\
\text { category }\end{array}$ & $\begin{array}{l}\text { Diagnostic } \\
\text { study } \\
\text { evidence } \\
\text { level }^{20}\end{array}$ & Number of patients & $\begin{array}{c}\text { Number of paired } \\
\text { blood tests }\end{array}$ & $\begin{array}{r}\text { Bacteraemia } \\
\text { prevalence (\%) }\end{array}$ \\
\hline Raglio [21] & 2006 & Abstract & Not stated & Not stated & Not stated & III & 74 & 114 & 15 \\
\hline Klemm [22] & 2007 & Abstract & Germany & Intensive/Critical Care & Not stated & III & 44 & 56 & 37 \\
\hline Bingold [23] & 2007 & Abstract & Germany & Intensive/Critical Care & Not stated & III & 21 & 134 & 15 \\
\hline Vince [24] & 2008 & Correspondence & Croatia & $\begin{array}{l}\text { In hospital and } \\
\text { Intensive/Critical Care }\end{array}$ & Not stated & III & 36 & 39 & 21 \\
\hline Mancini [25] & 2008 & Paper & Italy & $\begin{array}{l}\text { In hospital and unclear } \\
\text { if Intensive/Critical Care } \\
\#\end{array}$ & Adults & III & 34 & 103 & 20 \\
\hline Louie [26] & 2008 & Paper & USA & $\begin{array}{l}\text { Emergency } \\
\text { Department, In hospital } \\
\text { and Intensive/Critical } \\
\text { Care }\end{array}$ & Adults & III & 200 & 200 & 21 \\
\hline Lodes [27] & 2008 & Abstract & Germany & Intensive/Critical Care & Not stated & III & 137 & 358 & 13 \\
\hline Westh [28] & 2009 & Paper & Germany & Not stated & Not stated & III & 359 & 558 & 13 \\
\hline Varani [29] & 2009 & Paper & Italy & $\begin{array}{l}\text { In hospital and unclear } \\
\text { if Intensive/Critical Care } \\
\#\end{array}$ & $\begin{array}{l}\text { Adults and } \\
\text { children }\end{array}$ & III & 100 & 130 & 29 \\
\hline Palomares [30] & 2009 & Abstract & Spain & Intensive/Critical Care & Not stated & III & 73 & 76 & 13 \\
\hline
\end{tabular}




\begin{tabular}{|c|c|c|c|c|c|c|c|c|c|}
\hline Lodes [31] & 2009 & Paper & Germany & Intensive/Critical Care & Adults & III & 52 & 258 & 12 \\
\hline Dierkes [32] & 2009 & Paper & Germany & Intensive/Critical Care & Adults & IIII & 77 & 99 & 23 \\
\hline Dark [33] & 2009 & Correspondence & UK & Intensive/Critical Care & Adults & III & 50 & 90 & 12 \\
\hline Yanagihara [34] & 2010 & Paper & Japan & $\begin{array}{l}\text { In hospital and } \\
\text { Emergency Department }\end{array}$ & Not stated & III & 212 & 400 & 8 \\
\hline Wallet [35] & 2010 & Paper & France & Intensive/Critical Care & Adults & III & 72 & 102 & 10 \\
\hline Tsalik [36] & 2010 & Paper & USA & Emergency Department & Adults & III & 306 & 306 & 22 \\
\hline S'oki [37] & 2010 & Abstract & Hungary & $\begin{array}{l}\text { In hospital and } \\
\text { Intensive/Critical Care }\end{array}$ & Not stated & III & 159 & 162 & 24 \\
\hline Regueiro [38] & 2010 & Paper & Spain & $\begin{array}{l}\text { In hospital and } \\
\text { Intensive/Critical Care }\end{array}$ & Adults & III & 72 & 106 & 25 \\
\hline Maubon [39] & 2010 & Paper & France & $\begin{array}{l}\text { In hospital and unclear } \\
\text { if Intensive/Critical Care } \\
\#\end{array}$ & Not stated & III & 110 & 110 & 29 \\
\hline Lehmann [40] & 2010 & Paper & Germany & Intensive/Critical Care & Adults & III & 108 & 453 & 13 \\
\hline Bloos [41] & 2010 & Paper & $\begin{array}{l}\text { Germany, } \\
\text { France }\end{array}$ & Intensive/Critical Care & Adult & III & 142 & 236 & 17 \\
\hline Berger [42] & 2010 & Abstract & Austria & Neonatal Unit & Neonates & III & 38 & 38 & 45 \\
\hline Avolio [43] & 2010 & Paper & Italy & Emergency Department & Adult & III & 144 & 144 & 30 \\
\hline Vrioni [44] & 2011 & Abstract & Greece & Not stated & Not stated & III & 33 & 33 & 24 \\
\hline Sitnik [45] & 2011 & Abstract & Brazil & Intensive/Critical Care & Not stated & III & 114 & 114 & 14 \\
\hline
\end{tabular}




\begin{tabular}{|c|c|c|c|c|c|c|c|c|c|}
\hline Obara [46] & 2011 & Paper & Japan & $\begin{array}{l}\text { Emergency } \\
\text { Department, In hospital } \\
\text { and Intensive/Critical } \\
\text { Care }\end{array}$ & Adults & III & 54 & 78 & 15 \\
\hline Lucignano [47] & 2011 & Paper & Italy & $\begin{array}{l}\text { In hospital and } \\
\text { Intensive/Critical Care }\end{array}$ & $\begin{array}{l}\text { Neonates } \\
\text { and } \\
\text { children }\end{array}$ & III & 811 & 1553 & 10 \\
\hline Josefson [48] & 2011 & Paper & Sweden & In hospital & $\begin{array}{l}\text { Adults and } \\
\text { children }\end{array}$ & III & 1093 & 1141 & 12 \\
\hline Hettwer [49] & 2011 & Paper & Germany & Emergency Department & Adults & III & 153 & 113 & 45 \\
\hline Bravo [50] & 2011 & Paper & Spain & $\begin{array}{l}\text { In hospital and } \\
\text { Intensive/Critical Care }\end{array}$ & Adult & III & 53 & 53 & 47 \\
\hline Tschiedel [51] & 2012 & Paper & Germany & $\begin{array}{l}\text { In hospital and } \\
\text { Intensive/Critical Care }\end{array}$ & $\begin{array}{l}\text { Adults and } \\
\text { children }\end{array}$ & IIII & 75 & 110 & 17 \\
\hline Rath [52] & 2012 & Paper & Germany & Intensive/Critical Care & Adults & III & 170 & 225 & 36 \\
\hline Pasqualini [53] & 2012 & Paper & Italy & $\begin{array}{l}\text { In hospital and unclear } \\
\text { if Intensive/Critical Care }\end{array}$ & Not stated & III & 391 & 391 & 15 \\
\hline Mauro [54] & 2012 & Paper & Italy & $\begin{array}{l}\text { In hospital and unclear } \\
\text { if Intensive/Critical Care } \\
\#\end{array}$ & $\begin{array}{l}\text { Adult and } \\
\text { children }\end{array}$ & III & 79 & 79 & 41 \\
\hline Lodes [55] & 2012 & Paper & Germany & Intensive/Critical Care & Adults & III & 104 & 148 & 20 \\
\hline Guido [56] & 2012 & Paper & Italy & $\begin{array}{l}\text { In hospital and unclear } \\
\text { if Intensive/Critical Care } \\
\#\end{array}$ & Adults & III & 166 & 166 & 14 \\
\hline
\end{tabular}




\begin{tabular}{|c|c|c|c|c|c|c|c|c|c|}
\hline Grif [57] & 2012 & Paper & Austria & $\begin{array}{l}\text { In hospital and } \\
\text { Intensive/Critical Care }\end{array}$ & Not stated & IIII & 61 & 71 & 7 \\
\hline Leitner [58] & 2013 & Paper & Austria & Not stated & Not stated & III & 57 & 75 & 15 \\
\hline Herne [59] & 2013 & Paper & Estonia & $\begin{array}{l}\text { In hospital and } \\
\text { Intensive/Critical Care }\end{array}$ & Adults & III & 144 & 160 & 21 \\
\hline Burdino [60] & 2014 & Paper & Italy & $\begin{array}{l}\text { In hospital and } \\
\text { Intensive/Critical Care }\end{array}$ & Adults & III & 1024 & 1186 & 15 \\
\hline Avolio [61] & 2014 & Paper & Italy & $\begin{array}{l}\text { Emergency Department } \\
\text { and Intensive/Critical } \\
\text { Care }\end{array}$ & Adults & III & 525 & 525 & 25 \\
\hline
\end{tabular}




\begin{tabular}{|c|c|c|c|c|}
\hline Subgroup & $\begin{array}{l}\text { Sensitivity } \\
\qquad(95 \% \mathrm{Cl})\end{array}$ & $\begin{array}{l}\text { Specificity } \\
(95 \% \mathrm{Cl})\end{array}$ & \multicolumn{2}{|c|}{$\begin{array}{l}\text { Interaction test for } \\
\text { subgroup differences }\end{array}$} \\
\hline & & & $x^{2}$ & $p$ \\
\hline Papers & $0.67(0.62-0.73)$ & $0.88(0.85-0.90)$ & \multirow[b]{2}{*}{4.3} & \multirow[b]{2}{*}{0.12} \\
\hline Abstracts & $0.69(0.58-0.78)$ & $0.81(0.75-0.87)$ & & \\
\hline Emergency Department & $0.69(0.52-0.83)$ & $0.93(0.86-0.96)$ & \multirow[b]{2}{*}{3.2} & \multirow[b]{2}{*}{0.19} \\
\hline Other hospital setting & $0.67(0.61-0.72)$ & $0.86(0.83-0.89)$ & & \\
\hline ICU & $0.64(0.54-0.74)$ & $0.83(0.78-0.86)$ & \multirow[b]{2}{*}{5.8} & \multirow[b]{2}{*}{0.06} \\
\hline Other hospital setting & $0.68(0.54-0.80)$ & $0.89(0.85-0.93)$ & & \\
\hline Haemato-oncology & $0.66(0.61-0.71)$ & $0.86(0.84-0.89)$ & \multirow[b]{2}{*}{2.7} & \multirow[b]{2}{*}{0.26} \\
\hline All other patient groups & $0.78(0.64-0.87)$ & $0.88(0.79-0.93)$ & & \\
\hline $\begin{array}{l}\text { Stated Roche } \\
\text { involvement }\end{array}$ & $0.68(0.61-0.75)$ & $0.88(0.85-0.91)$ & \multirow[t]{2}{*}{2.1} & \multirow[t]{2}{*}{0.35} \\
\hline Not stated & $0.67(0.61-0.73)$ & $0.85(0.81-0.88)$ & & \\
\hline
\end{tabular}

Table 3: Planned sub-group analyses. 


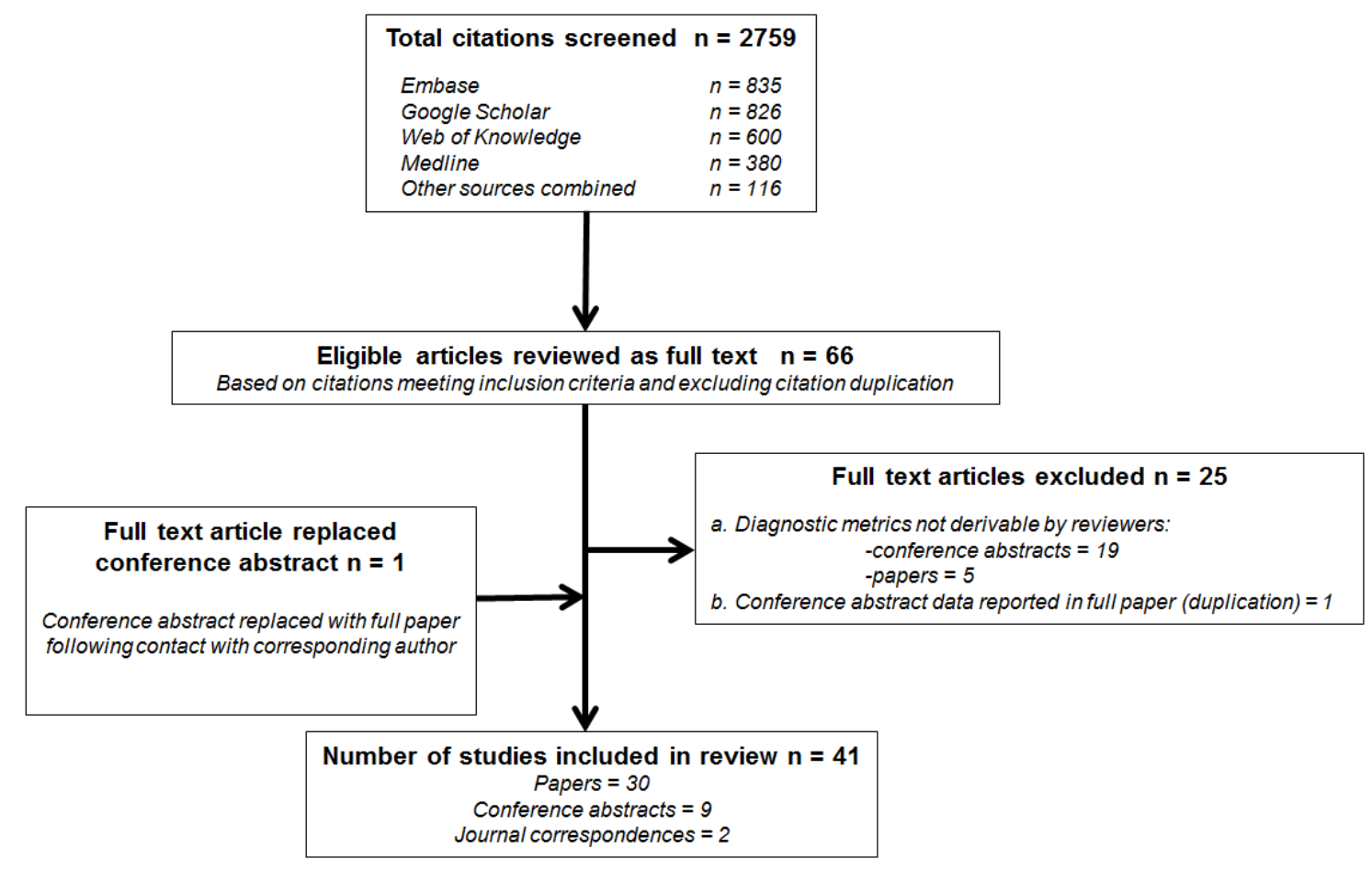

Figure 1: Flow diagram of study selection 


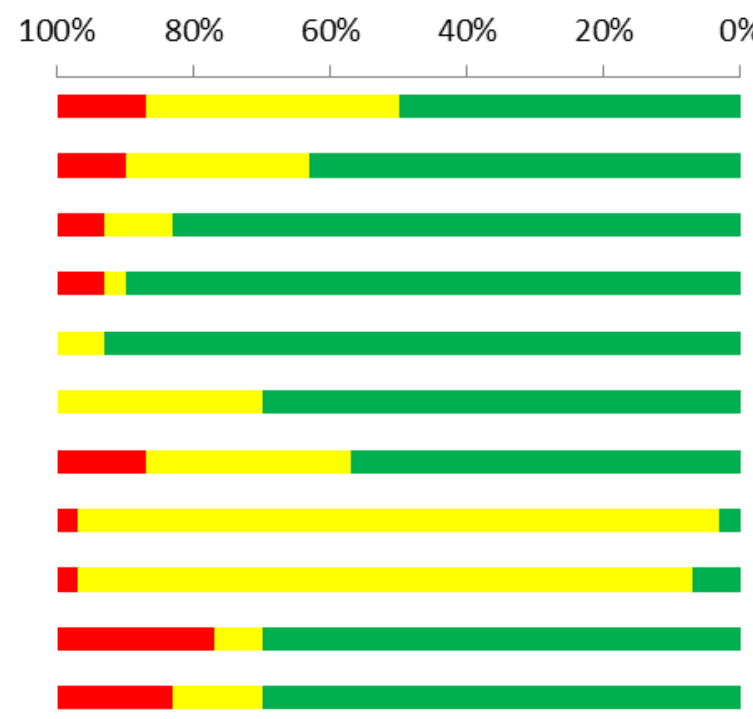

Papers

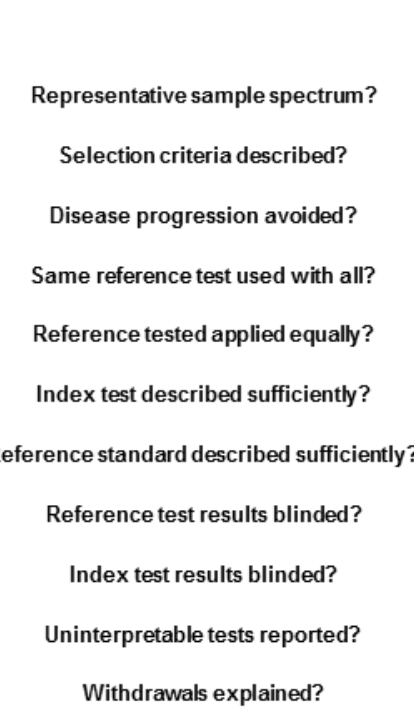

Withdrawals explained?

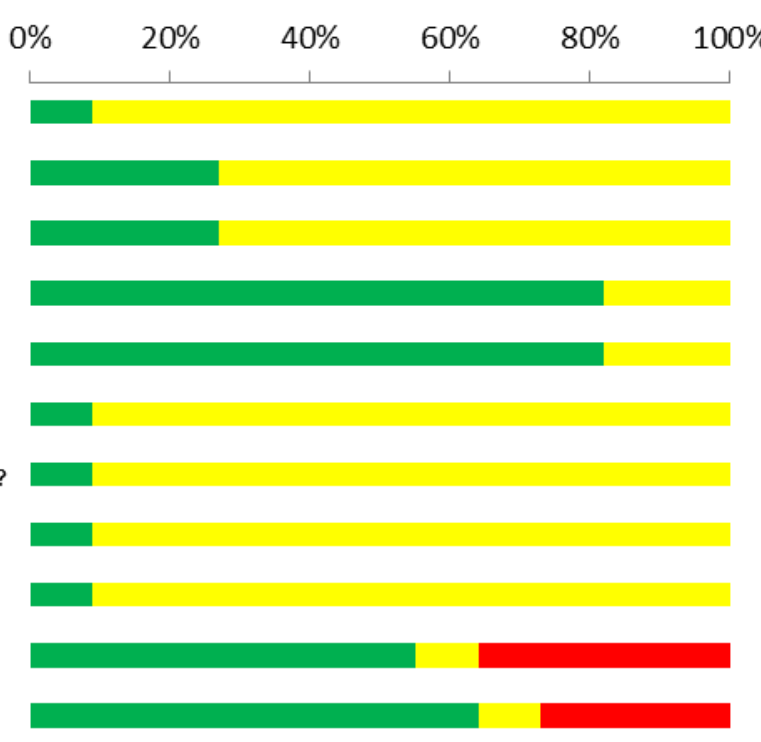

Abstracts and correspondences

Figure 2: Summary of independent review of quality of included studies. (Green $=$ yes, yellow $=$ uncertain and red $=$ no) 


\begin{tabular}{|c|c|c|c|c|c|c|c|c|}
\hline Study & TP & FP & FN & TN & Sensitivity $(95 \% \mathrm{CI})$ & Specificity $(95 \% \mathrm{CI})$ & Sensitivity $(95 \% \mathrm{Cl})$ & Specificity $(95 \% \mathrm{Cl})$ \\
\hline Avolio 2010 & 30 & 10 & 13 & 91 & $0.70[0.54,0.83]$ & $0.90[0.83,0.95]$ & & \\
\hline Avolio 2014 & 83 & 40 & 56 & 356 & $0.60[0.51,0.68]$ & $0.90[0.86,0.93]$ & & \\
\hline Berger 2010 & 17 & 9 & 0 & 12 & $1.00[0.80,1.00]$ & $0.57[0.34,0.78]$ & & \\
\hline Bingold 2007 & 10 & 52 & 10 & 62 & $0.50[0.27,0.73]$ & $0.54[0.45,0.64]$ & & - \\
\hline Bloos 2010 & 31 & 51 & 8 & 146 & $0.79[0.64,0.91]$ & $0.74[0.67,0.80]$ & & \\
\hline Bravo 2011 & 12 & 4 & 13 & 24 & $0.48[0.28,0.69]$ & $0.86[0.67,0.96]$ & & \\
\hline Burdino 2014 & 131 & 75 & 50 & 893 & $0.72[0.65,0.79]$ & $0.92[0.90,0.94]$ & & \\
\hline Dark 2009 & 9 & 9 & 2 & 73 & $0.82[0.48,0.98]$ & $0.89[0.80,0.95]$ & & \\
\hline Dierkers 2009 & 14 & 13 & 9 & 63 & $0.61[0.39,0.80]$ & $0.83[0.73,0.91]$ & & \\
\hline Grif 2012 & 5 & 12 & 3 & 51 & $0.63[0.24,0.91]$ & $0.81[0.69,0.90]$ & & \\
\hline Guido 2012 & 21 & 17 & 2 & 126 & $0.91[0.72,0.99]$ & $0.88[0.82,0.93]$ & & \\
\hline Herne 2013 & 30 & 41 & 12 & 99 & $0.71[0.55,0.84]$ & $0.71[0.62,0.78]$ & & \\
\hline Hettwer 2011 & 39 & 5 & 12 & 57 & $0.76[0.63,0.87]$ & $0.92[0.82,0.97]$ & & \\
\hline Josefson 2011 & 50 & 64 & 86 & 896 & $0.37[0.29,0.45]$ & $0.93[0.92,0.95]$ & & \\
\hline Klemm 2008 & 13 & 5 & 8 & 30 & $0.62[0.38,0.82]$ & $0.86[0.70,0.95]$ & & \\
\hline Lehmann 2010 & 40 & 74 & 18 & 321 & $0.69[0.55,0.80]$ & $0.81[0.77,0.85]$ & & \\
\hline Leitner 2013 & 3 & 8 & 4 & 60 & $0.43[0.10,0.82]$ & $0.88[0.78,0.95]$ & & \\
\hline Lodes 2008 & 25 & 41 & 21 & 271 & $0.54[0.39,0.69]$ & $0.87[0.83,0.90]$ & & \\
\hline Lodes 2009 & 12 & 21 & 20 & 205 & $0.38[0.21,0.56]$ & $0.91[0.86,0.94]$ & & \\
\hline Lodes 2011 & 25 & 34 & 5 & 84 & $0.83[0.65,0.94]$ & $0.71[0.62,0.79]$ & & \\
\hline Louie 2008 & 28 & 17 & 15 & 140 & $0.65[0.49,0.79]$ & $0.89[0.83,0.94]$ & & \\
\hline Lucignano 2011 & 136 & 90 & 24 & 1303 & $0.85[0.79,0.90]$ & $0.94[0.92,0.95]$ & & \\
\hline Mancini 2008 & 20 & 14 & 1 & 68 & $0.95[0.76,1.00]$ & $0.83[0.73,0.90]$ & & \\
\hline Maubon 2010 & 17 & 11 & 15 & 67 & $0.53[0.35,0.71]$ & $0.86[0.76,0.93]$ & & \\
\hline Mauro 2012 & 27 & 5 & 5 & 42 & $0.84[0.67,0.95]$ & $0.89[0.77,0.96]$ & & \\
\hline Obara 2011 & 11 & 10 & 1 & 56 & $0.92[0.62,1.00]$ & $0.85[0.74,0.92]$ & & \\
\hline Palomares 2009 & 7 & 10 & 3 & 56 & $0.70[0.35,0.93]$ & $0.85[0.74,0.92]$ & & \\
\hline Pasquilani 2012 & 32 & 28 & 25 & 306 & $0.56[0.42,0.69]$ & $0.92[0.88,0.94]$ & & \\
\hline Raglio 2006 & 13 & 24 & 4 & 73 & $0.76[0.50,0.93]$ & $0.75[0.65,0.83]$ & & ( \\
\hline Rath 2012 & 57 & 35 & 23 & 110 & $0.71[0.60,0.81]$ & $0.76[0.68,0.83]$ & & \\
\hline Reguerio 2010 & 17 & 1 & 10 & 78 & $0.63[0.42,0.81]$ & $0.99[0.93,1.00]$ & & \\
\hline S'oki 2010 & 21 & 18 & 18 & 102 & $0.54[0.37,0.70]$ & $0.85[0.77,0.91]$ & & \\
\hline Sitnik 2011 & 12 & 10 & 4 & 88 & $0.75[0.48,0.93]$ & $0.90[0.82,0.95]$ & & \\
\hline Tsalik 2010 & 40 & 13 & 26 & 227 & $0.61[0.48,0.72]$ & $0.95[0.91,0.97]$ & & \\
\hline Tschiedel 2012 & 12 & 14 & 7 & 77 & $0.63[0.38,0.84]$ & $0.85[0.76,0.91]$ & & \\
\hline Varani 2009 & 22 & 10 & 16 & 82 & $0.58[0.41,0.74]$ & $0.89[0.81,0.95]$ & & \\
\hline Vince 2008 & 4 & 9 & 4 & 22 & $0.50[0.16,0.84]$ & $0.71[0.52,0.86]$ & & \\
\hline Vrioni 2011 & 7 & 1 & 1 & 24 & $0.88[0.47,1.00]$ & $0.96[0.80,1.00]$ & & \\
\hline Wallet 2010 & 4 & 11 & 6 & 81 & $0.40[0.12,0.74]$ & $0.88[0.80,0.94]$ & & \\
\hline Westh 2009 & 50 & 124 & 24 & 382 & $0.68[0.56,0.78]$ & $0.75[0.72,0.79]$ & & \\
\hline Yanagihara 2010 & 22 & 23 & 10 & 345 & $0.69[0.50,0.84]$ & $0.94[0.91,0.96]$ & & \\
\hline
\end{tabular}

Figure 3: Forest plot of included studies 


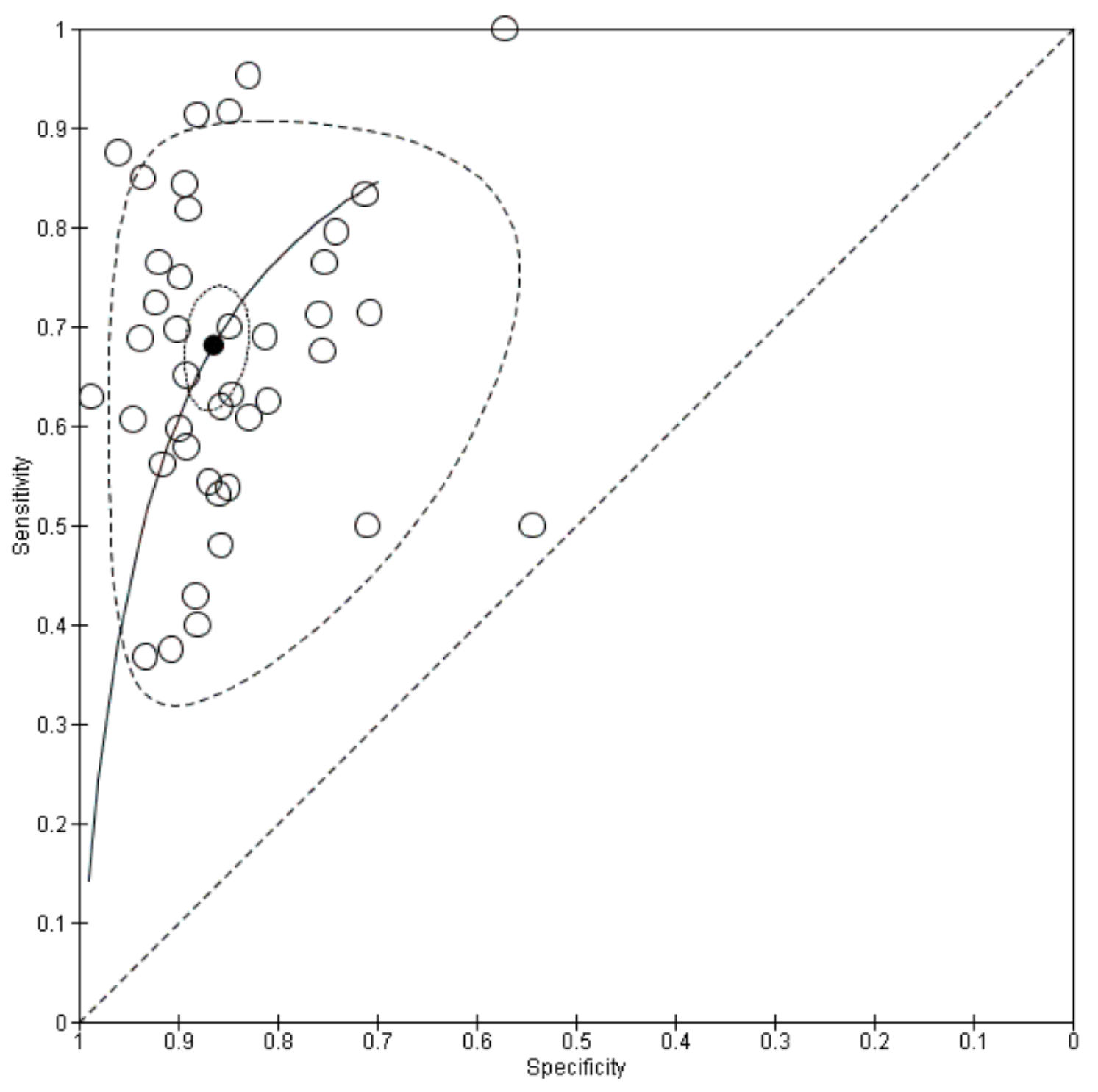

Figure 4: Summary Receiver Operator Curve (ROC), with 95\% confidence region (dotted) and $95 \%$ prediction region (dashed) 


\section{$\underline{\text { References }}$}

1. Bone RC, Sibbald WJ, Sprung CL (1992) The ACCP-SCCM consensus conference on sepsis and organ failure. Chest 101:1481-3

2. Dellinger RP, Levy MM, Rhodes A, Annane D, Gerlach, H. Opal SM, Sevransky JE, Sprung CL, Douglas I S, Jaeschke R, Osborn TM, Nunnally ME, Townsend SR, Reinhart K, Kleinpell RM, Angus DC, Deutschman CS, Machado FR, Rubenfeld GD, Webb , Beale RJ, Vincent JL, Moreno R (2012) Surviving Sepsis Campaign: international guidelines for management of severe sepsis and septic shock. Intensive Care Med 39:165-228

3. Calandra T, Cohen $\mathrm{J}$ (2005) The international sepsis forum consensus conference on definitions of infection in the intensive care unit. Crit Care Med 33:1538-48

4. Health Protection Agency (2005) Investigation of blood cultures (for organisms other than mycobacterium species). National Standard Method, Standards Unit, London

5. Comptroller Auditor General (2009) Reducing healthcare associated infection in hospitals in England. HC 560 Session 2008-2009. The Stationery Office, London

6. Kollef MH, Sherman G, Ward S, Fraser VJ (1999) Inadequate antimicrobial treatment of infections: a risk factor for hospital mortality among critically ill patients. Chest 115:462-74

7. Kumar A, Roberts D, Wood KE, Light B, Parrillo JE, Sharma S, Suppes R, Feinstein D, Zanotti S, Taiberg L, Gurka D, Kumar A, Cheang M (2006) Duration of hypotension before initiation of effective antimicrobial therapy is the critical determinant of survival in human septic shock. Crit Care Med $34: 1589-96$

8. World Health Organisation (2012) The evolving threat of antimicrobial resistance: Options for action. World Health Organisation

9. Peters RP, van Agtmael MA, Danner SA, Savelkoul PH, VandenbrouckeGrauls CM (2004) New developments in the diagnosis of bloodstream infections. Lancet Infect Dis 4:751-60

10. Dark PM, Dean P, Warhurst G (2009) Bench-to-bedside review: the promise of rapid infection diagnosis during sepsis using polymerase chain reactionbased pathogen detection. Crit Care 13: 217

11. Lehmann LE, Hunfeld KP, Emrich T, Haberhausen G, Wissing H, Hoeft A, Stuber $F$ (2008) A multiplex real-time PCR assay for rapid detection and differentiation of 25 bacterial and fungal pathogens from whole blood samples. Med Microbiol Immunol 197:313-24 
12. Chang SS, Hsieh WH, Liu TS, Lee SH, Wang CH, Chou HC, Yeo YH, Tseng CP, Lee CC (2013) Multiplex PCR system for rapid detection of pathogens in patients with presumed sepsis - a systemic review and meta-analysis. PLoS One 8:e62323

13. Dark PM, Dunn G, Chadwick P, Young D, Bentley A, Carlson G, Warhurst G (2011) The clinical diagnostic accuracy of rapid detection of healthcareassociated bloodstream infection in intensive care using multi-pathogen realtime polymerase chain reaction (real-time PCR) technology. BMJ Open $1: e 000181$

14. Dark P, Wilson C, Blackwood B, McAuley DF, Perkins GD, McMullan R, Gates S, Warhurst G (2011) Accuracy of LightCycler SeptiFast for the Detection and Identification of Pathogens in Blood of Patients with Suspected Sepsis: A Systematic Review. PROSPERO CRD42011001289.

http://www.crd.york.ac.uk/PROSPERO/full_doc.asp?ID=CRD42011001289

15. Dark P, Wilson C, Blackwood B, McAuley DF, Perkins GD, McMullan R, Gates S, Warhurst G (2012) Accuracy of LightCycler(R) SeptiFast for the detection and identification of pathogens in the blood of patients with suspected sepsis: a systematic review protocol. BMJ Open 2:e000392

16. Levy MM, Fink MP, Marshall JC, Abraham E, Angus D, Cook D, Cohen J, Opal SM, Vincent JL, Ramsay G (2003) 2001 SCCM/ESICM/ACCP/ATS/SIS International Sepsis Definitions Conference. Intensive Care Med 29:530-8

17. Whiting P, Rutjes AW, Reitsma JB, Bossuyt PM, Kleijnen J (2003) The development of QUADAS: a tool for the quality assessment of studies of diagnostic accuracy included in systematic reviews. BMC Med Res Methodol 3: 25

18. Reitsma JB, Glas AS, Rutjes AW, Scholten RJ, Bossuyt PM, Zwinderman AH (2005) Bivariate analysis of sensitivity and specificity produces informative summary measures in diagnostic reviews. J Clin Epidemiol 58(10): 982-90

19. Harbord RM, Deeks JJ, Egger M, Whiting P, Sterne JA (2007) A unification of models for meta-analysis of diagnostic accuracy studies. Biostatistics 8:23951

20. Phillips B, Ball C, Sackett D, Badenoch D, Straus S, Haynes B, Dawes M (2001) Oxford Centre for Evidence-based Medicine Levels of Evidence. http://www.cebm.net/index.aspx?O=1025. Accessed 6 Jan 2012

21. Raglio A, Rizzi M, Amer M, Mangia M, Lucà M, Goglio A (2006) Sepsis diagnosis by realtime PCR (SeptiFast Kit, Roche Diagnostics). 16th European Congress of Clinical Microbiology and Infectious Diseases, 2006, Nice, France. Blackwell Publishing 
22. Klemm M, Prinz M, Nowak ,. Morgenstern T, Meisner M, Rothe KF, Demant T (2007) Clinical application of SeptiFast, a PCR method for the detection of bacteraemia, in intensive care patients. Infection 35:12

23. Bingold TM, Hunfeld K, Scheller B, Rönneberg T, Sartorius S, Wahrmann M, Klösel S, Zwißler B, Wissing H (2007) Clinical utility of a new PCR-based assay for rapid pathogen detection (SeptiFast $\left.{ }^{\circledR}\right)$ in patients with clinical sepsis compared to standard blood culture. Infection 35:15

24. Vince A, Lepej SZ, Barsic B, Dusek D, Mitrovic Z, Serventi-Seiwerth R, Labar B (2008) LightCycler SeptiFast assay as a tool for the rapid diagnosis of sepsis in patients during antimicrobial therapy. J Med Microbiol 57:1306-7

25. Mancini, N. Clerici, D. Diotti, R. Perotti, M. Ghidoli, N. De Marco, D. Pizzorno, B. Emrich, T. Burioni, R. Ciceri, F. Clementi, M (2008) Molecular diagnosis of sepsis in neutropenic patients with haematological malignancies. J Med Microbiol 57:601-4

26. Louie RF, Tang Z, Albertson TE, Cohen S, Tran NK, Kost GJ (2008) Multiplex polymerase chain reaction detection enhancement of bacteremia and fungemia. Crit Care Med 36: 1487-92

27. Lodes U, Bohmeier B, Meyer F, Koenig B, Lippert H (2008) Microbiologic diagnostic with the novel lightcycler septifast ${ }^{\circledR}$ test during the early phase of surgical sepsis mainly caused by peritonitis is quicker and more sensitive than conventional microbiological culture. Gastroenterology 134: A621

28. Westh H, Lisby G, Breysse F, Boddinghaus B, Chomarat M, Gant V, Goglio A, Raglio A, Schuster H, Stuber F, Wissing, Hoeft A (2009) Multiplex real-time PCR and blood culture for identification of bloodstream pathogens in patients with suspected sepsis. Clin Microbiol Infect 15:544-51

29. Varani S, Stanzani M, Paolucci M, Melchionda F, Castellani G, Nardi L, Landini MP, Baccarani M, Pession A, Sambri V (2009) Diagnosis of bloodstream infections in immunocompromised patients by real-time PCR. J Infect 58:346-51

30. Palomares J, Puche B, Martos A, Lucena F, Marín M, Martín-Mazuelos E (2009) Rapid molecular diagnosis of severe sepsis in patients with symptoms of severe sepsis. 19th European Congress of Clinical Microbiology and Infectious Diseases, 2009, Helsiniki, Finland. Blackwell Publishing, P1827

31. Lodes U, Meyer F, Konig B, Lippert H (2009) Microbiological sepsis screening in surgical ICU patients with the "lightCycler" Septifast test--a pilot study. Zentralbl Chir 134:249-53 
32. Dierkes C, Ehrenstein B, Siebig S, Linde HJ, Reischl U, Salzberger B (2009) Clinical impact of a commercially available multiplex PCR system for rapid detection of pathogens in patients with presumed sepsis. BMC Infect Dis 9: 126.

33. Dark P, Chadwick P, Warhurst G (2009) Detecting sepsis-associated bloodstream infection acquired in intensive care using multi-pathogen realtime PCR. J Infect 59:296-8

34. Yanagihara K, Kitagawa Y, Tomonaga M, Tsukasaki K, Kohno S, Seki M, Sugimoto H, Shimazu T, Tasaki O, Matsushima A, Ikeda Y, Okamoto S, Aikawa N, Hori S, Obara H, Ishizaka A, Hasegawa N, Takeda J, Kamihira S, Sugahara K, Asari S, Murata M, Kobayashi Y, Ginba H, Sumiyama Y, Kitajima M (2010) Evaluation of pathogen detection from clinical samples by real-time polymerase chain reaction using a sepsis pathogen DNA detection kit. Crit Care 14: R159

35. Wallet F, Nseir S, Baumann L, Herwegh S, Sendid B, Boulo M, RousselDelvallez M, Durocher AV, Courcol RJ (2010) Preliminary clinical study using a multiplex real-time PCR test for the detection of bacterial and fungal DNA directly in blood. Clin Microbiol Infect 16:774-9

36. Tsalik EL, Jones D, Nicholson B, Waring L, Liesenfeld O, Park LP, Glickman SW, Caram LB, Langley RJ, van Velkinburgh JC, Cairns CB, Rivers EP, Otero RM, Kingsmore SF, Lalani T, Fowler VG, Woods CW (2010) Multiplex PCR to diagnose bloodstream infections in patients admitted from the emergency department with sepsis. J Clin Microbiol 48:26-33

37. Sóki J, Szabó E, Hajdú E, Lázár A, Nagy E (2010) Use of a commercially available multiplex real-time PCR assay (SeptiFast) to detect bacterial and fungal pathogens in septic patients. 20th European Congress of Clinical Microbiology and Infectious Diseases, 2010, Vienna, Austria. European Congress of Clinical Microbiology and Infectious Diseases

38. Regueiro BJ, Varela-Ledo E, Martinez-Lamas L, Rodriguez-Calvino J, Aguilera A, Santos A, Gomez-Tato A, Alvarez-Escudero J (2010) Automated extraction improves multiplex molecular detection of infection in septic patients. PLoS One 5:e13387

39. Maubon D, Hamidfar-Roy R, Courby S, Vesin A, Maurin M, Pavese P, Ravanel N, Bulabois CE, Brion JP, Pelloux H, Timsit JF (2010) Therapeutic impact and diagnostic performance of multiplex PCR in patients with malignancies and suspected sepsis. J Infect 61:335-42

40. Lehmann LE, Hunfeld KP, Steinbrucker M, Brade V, Book M, Seifert H, Bingold T, Hoeft A, Wissing H, Stuber F (2010) Improved detection of blood stream pathogens by real-time PCR in severe sepsis. Intensive Care Med 36:49-56 
41. Bloos F, Hinder F, Becker K, Sachse S, Mekontso Dessap A, Straube E, Cattoir V, Brun-Buisson C, Reinhart K, Peters G, Bauer M (2010) A multicenter trial to compare blood culture with polymerase chain reaction in severe human sepsis. Intensive Care Med 36:241-7

42. Berger A, Altiok I, Mechtler T, Langgartner M, Böhm J, Herkner K, Pollack A, Kasper D (2010) Adaption of the Roche SeptiFast system for the early detection of neonatal sepsis in very low birthweight infants. Klinische Pädiatrie 222:S4

43. Avolio M, Diamante P, Zamparo S, Modolo ML, Grosso S, Zigante P, Tosoni N, De Rosa R, Stano P, Camporese A (2010) Molecular identification of bloodstream pathogens in patients presenting to the emergency department with suspected sepsis. Shock 34:27-30

44. Vrioni G, Daniil I, Mamali V, Kimouli M, Mylona-Petropoulou D, ThemeliDigalaki K, Tsakris A (2011) Preliminary clinical study using a multiplex blood PCR for rapid detection of bacterial and fungal pathogens in ICU patients with presumed sepsis. 21st European Congress of Clinical Microbiology and Infectious Diseases, 2011, Milan, Italy. European Congress of Clinical Microbiology and Infectious Diseases

45. Sitnik R, Marra AR, Petroni RC, Ramos OP,Martino MD, Pasternak J, Santos OS, Mangueira CL, Rebello Pinho JR (2011) SeptiFast for Diagnosis of Sepsis in Severely III Patients from a Brazilian Hospital. Journal of Medical Diagnsotics 13:736

46. Obara H, Aikawa N, Hasegawa N, Hori S, Ikeda Y, Kobayashi Y, Murata M, Okamoto S, Takeda J, Tanabe M, Sakakura Y, Ginba H, Kitajima M, Kitagawa, Y (2011) The role of a real-time PCR technology for rapid detection and identification of bacterial and fungal pathogens in whole-blood samples. $J$ Infect Chemother 17:327-33.

47. Lucignano B, Ranno S, Liesenfeld O, Pizzorno B, Putignani L, Bernaschi $\mathrm{P}$, Menichella D (2011) Multiplex PCR allows rapid and accurate diagnosis of bloodstream infections in newborns and children with suspected sepsis. J Clin Microbiol 49:2252-8

48. Josefson P, Stralin K, Ohlin A, Ennefors T, Dragsten B, Andersson L, Fredlund $\mathrm{H}$, Molling $\mathrm{P}$, Olcen $\mathrm{P}$ (2011) Evaluation of a commercial multiplex PCR test (SeptiFast) in the etiological diagnosis of community-onset bloodstream infections. Eur J Clin Microbiol Infect Dis 30:1127-34

49. Hettwer S, Wilhelm J, Schurmann M, Ebelt $H$, Hammer D, Amoury M, Hofmann F, Oehme A, Wilhelms D, Kekule AS, Kloss T, Werdan K (2011) Microbial diagnostics in patients with presumed severe infection in the emergency department. Med Klin Intensivmed Notfmed 107:53-62 
50. Bravo D, Blanquer J, Tormo M, Aguilar G, Borras R, Solano C, Clari MA, Costa E, Munoz-Cobo B, Argueso M, Pineda JR, Navarro D (2011) Diagnostic accuracy and potential clinical value of the LightCycler SeptiFast assay in the management of bloodstream infections occurring in neutropenic and critically ill patients. Int J Infect Dis 15:e326-31

51. Tschiedel E, Steinmann J, Buer J, Onnebrink JG, Felderhoff-Muser U, Rath PM, Dohna-Schwake C (2012) Results and relevance of molecular detection of pathogens by SeptiFast--a retrospective analysis in 75 critically ill children. Klin Padiatr 224:12-6

52. Rath PM, Saner F, Paul A, Lehmann N, Steinmann E, Buer J, Steinmann J (2012) Multiplex PCR for rapid and improved diagnosis of bloodstream infections in liver transplant recipients. J Clin Microbiol 50:2069-71

53. Pasqualini L, Mencacci A, Leli C, Montagna P, Cardaccia A, Cenci E, Montecarlo I, Pirro M,di Filippo F, Cistaro E, Schillaci G, Bistoni F, Mannarino E (2012) Diagnostic performance of a multiple real-time PCR assay in patients with suspected sepsis hospitalized in an internal medicine ward. J Clin Microbiol 50:1285-8

54. Mauro MV, Cavalcanti P, Perugini D, Noto A, Sperli D, Giraldi C (2012) Diagnostic utility of LightCycler SeptiFast and procalcitonin assays in the diagnosis of bloodstream infection in immunocompromised patients. Diagn Microbiol Infect Dis 73:308-11

55. Lodes U, Bohmeier B, Lippert H, Konig B, Meyer F (2012) PCR-based rapid sepsis diagnosis effectively guides clinical treatment in patients with new onset of SIRS. Langenbecks Arch Surg 397:447-55

56. Guido M, Quattrocchi M, Zizza A, Pasanisi G, Pavone V, Lobreglio G, Gabutti G, De Donno A (2012) Molecular approaches in the diagnosis of sepsis in neutropenic patients with haematological malignances. J Prev Med Hyg 53:104-8

57. Grif K, Fille M, Wurzner R, Weiss G, Lorenz I, Gruber G, Eschertzhuber S, Nachbaur D, Lass-Florl C, Orth D (2012) Rapid detection of bloodstream pathogens by real-time PCR in patients with sepsis. Wien Klin Wochenschr 124:266-70

58. Leitner E, Kessler HH, Spindelboeck W, Hoenigl M, Putz-Bankuti C, Stadlbauer-Kollner V, Krause R, Grisold AJ, Feierl G, Stauber RE (2013) Comparison of two molecular assays with conventional blood culture for diagnosis of sepsis. J Microbiol Methods 3:253-5

59. Herne V, Nelovkov A, Kütt M, Ivanova M (2013) Diagnostic performance and therapeutic impact of LightCycler SeptiFast assays in patients with suspected sepsis. Eur J Microbiol Immunol 3:68-76 
60. Burdino E, Ruggiero T, Allice T, Milia MG, Gregori G, Milano R, Cerutti F, De Rosa FG, Manno E, Caramello P, Di Perri G, Ghisetti V (2014) Combination of blood cultures and SeptiFast molecular test in aptients with suspected sepsis for the identification of bloodstream pathogens. Diagn Microbiol Infect Dis 79:287-92

61. Avolio M, Diamante P, Modolo ML, DeRosa R, Stano P, Camporese A (2014) Direct molecualr detection of pathogens in blood as specific rule-in diagnsotic biomarker in patients with presumed sepsis: our experince on a heterogeneous cohort of patients with signs of infective systemic inflammatory response syndrome. Shock 42:86-92

62. Bossuyt PM, Reitsma JB, Bruns DE, Gatsonis CA, Glasziou PP, Irwig LM, Lijmer JG, Moher D, Rennie D, de Vet HC (2003) Towards complete and accurate reporting of studies of diagnostic accuracy: the STARD initiative. BMJ 326:41-4

63. Rutjes AWS, Reitsma JB, Coomarasamy A, Khan KS, Bossuyt PMM (2007) Evaluation of diagnostic tests when there is no gold standard. A review of methods. Health Technol Assess 11 


\section{Acknowledgements:}

We thank Mrs Helen McEvoy, formerly at the University of Manchester, School of Medicine Library, for her assistance with search strategy design and Mrs Valerie Haigh, Salford Royal NHS Foundation Trust Library and Information Resource Centre, for her advice on the use of filters in diagnostic search strategies.

\section{Funding:}

PD and GW were part-funded by the UK Health Technology Assessment (HTA) programme of the National Institute of Health Research grant number NIHR HTA 08/13/16. CW and DG were funded by NIHR Greater Manchester Comprehensive Local Research Network in support of this programme of work. DFM and GDP receive funding from The Intensive Care Foundation (UK) in support of their roles as National Research Directors. None of these funding organisations or any commercial organisation have contributed to the study design; collection, management, analysis and interpretation of data; writing of the report or the decision to submit the report for publication. Only the named authors have ultimate authority over each of these activities.

Competing interests: None.

\section{Contributors:}

PD and GW initiated the project, $\mathrm{BB}$ and $\mathrm{CW}$ worked on the initial architecture for the review with specialist molecular diagnostic input from GW, critical care and clinical trial input from PD, DM and GDP, microbiological input from RM and statistical input from SG. CW, DG, KT and PD ran the search strategies and selected the full text manuscripts for review. DM and GDP reviewed the studies with BB and RM. SG designed and conducted the statistical analyses. PD drafted the manuscript and all authors critically reviewed the first draft and contributed to the production of the final manuscript.

\section{Study registration:}

PROSPERO - NIHR Prospective Register of Systematic Reviews (CRD42011001289). 